\title{
MRI for managing intermediate \& low risk prostate cancer
}

\author{
Anwar R Padhani \\ From International Cancer Imaging Society (ICIS) 14th Annual Teaching Course \\ Heidelberg, Germany. 9-11 October 2014
}

\section{Intermediate risk disease}

Pathological status: PSA $10-20 \mathrm{ng} / \mathrm{mL}$, or biopsy Gleason score 7, or clinical stage T2b or T2c

Clinical note: Heterogeneous group with a wide incidence of biochemical relapse \& numerous curative therapy options.

Problems with categorization: Detection of unfavourable subgroup includes Gleason $\geq 4+3$ and/or $>50 \%$ positive biopsies and/or $>1$ intermediate risk factors [1,2]

Role of MRI in practice:

1. If initial active surveillance is considered, then it is important not to underestimate tumor grade/ volume/stage

2. For external beam radiotherapy, the presence of unfavourable disease affects duration of adjuvant hormonal therapy.

3. For focal therapy, index lesion localization is needed

4. For surgery, accurate staging to enable curative treatment with negative margins \& nerve sparing if possible

Type of MRI [3]:

- Lesion detection and localisation protocol with T2W, DW-MRI and DCE-MRI \pm MRSI for low ADC lesions to assess aggressiveness

- Staging with multi-planar T2W, DW-MRI \pm DCEMRI for ECE/SVI

\section{High risk disease}

Pathological status: PSA $>20 \mathrm{ng} / \mathrm{mL}$, or Gleason score $8-10$, or clinical stage $>\mathrm{T} 2 \mathrm{c}$

Correspondence: anwar.padhani@stricklandscanner.org.uk Mount Vernon Cancer Centre, London, UK
Clinical note: Highest risk of biochemical recurrence and cancer specific mortality but substantial population heterogeneity

Prognostic subgroups [4]:

- Good prognosis subgroup: one single risk factor (any)

- Intermediate prognosis subgroup: two risk factors (PSA >20 ng/ml and stage cT3-4); No Gleason 8+ disease

- Poor prognosis subgroup: GS >7 and stage cT3-4 and/or PSA $>20 \mathrm{ng} / \mathrm{ml}$

Clinical sub-groups: localized, locally advanced \& metastatic

Problems with categorization: Local staging accuracy \& the detection of metastatic disease

Role of MRI in practice

1. local and nodal staging: to detect extensive ECE/ SVI that would preclude radical surgery with negative margins. Nerve sparing rarely undertaken.

2. To detect nodal and bone metastases

Type of MRI [3,5]:

- Accurate local staging and pelvic nodal assessments

- Bone scan + CT abdomen or WB-MRI

Published: 9 October 2014

\section{References}

1. D'Amico AV: Personalizing the management of men with intermediaterisk prostate cancer. Eur Urol 2013, 64(6):903-4.

2. Keane FK, Chen MH, Zhang D, Loffredo MJ, Kantoff PW, Renshaw AA, D'Amico AV: The likelihood of death from prostate cancer in men with favorable or unfavourable intermediate-risk disease. Cancer 2014, 120(12):1787-93.

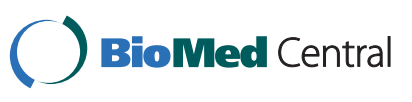

(c) 2014 Padhani; licensee BioMed Central Ltd. This is an Open Access article distributed under the terms of the Creative Commons Attribution License (http://creativecommons.org/licenses/by/4.0), which permits unrestricted use, distribution, and reproduction in any medium, provided the original work is properly cited. The Creative Commons Public Domain Dedication waiver (http://creativecommons.org/publicdomain/zero/1.0/) applies to the data made available in this article, unless otherwise stated. 
3. Cornud F, Delongchamps NB, Mozer P, Beuvon F, Schull A, Muradyan N, Peyromaure M: Value of multiparametric MRI in the work-up of prostate cancer. Curr Urol Rep 2012, 13(1):82-92.

4. Joniau S, Briganti A, Gontero P, Gandaglia G, Tosco L, Fieuws S, Tombal B, Marchioro G, Walz J, Kneitz B, Bader P, Frohneberg D, Tizzani A, Graefen M van Cangh P, Karnes RJ, Montorsi F, Van Poppel H, Spahn M: European Multicenter Prostate Cancer Clinical and Translational Research Group (EMPaCT). Stratification of High-risk Prostate Cancer into Prognostic Categories: A European Multi-institutional Study. Eur Urol 2014, S0302-2838(14):00071-2.

5. Lecouvet FE, Lhommel R, Pasoglou V, Larbi A, Jamar F, Tombal B: Novel imaging techniques reshape the landscape in high-risk prostate cancers. Curr Opin Urol 2013, 23(4):323-30.

doi:10.1186/1470-7330-14-S1-O9

Cite this article as: Padhani: MRI for managing intermediate \& low risk prostate cancer. Cancer Imaging 2014 14(Suppl 1):09.

\section{Submit your next manuscript to BioMed Central} and take full advantage of:

- Convenient online submission

- Thorough peer review

- No space constraints or color figure charges

- Immediate publication on acceptance

- Inclusion in PubMed, CAS, Scopus and Google Scholar

- Research which is freely available for redistribution

Submit your manuscript at www.biomedcentral.com/submit
Ciomed Central 